\title{
MASTER
}

\section{The Functions Of An Engineered Barrier System For A Nuclear Waste Repository In Basalt}

W. E. Coons

E. L. Moore

M. J. Smith

J. D. Kaser

Prepared for the United States

Department of Energy

Under Contract DE-AC06-77RL01030

Rockwell International

Rockwell Hanford Operations Energy Systems Group Richland, WA 99352 


\section{DISCLAIMER}

This report was prepared as an account of work sponsored by an agency of the United States Government. Neither the United States Government nor any agency Thereof, nor any of their employees, makes any warranty, express or implied, or assumes any legal liability or responsibility for the accuracy, completeness, or usefulness of any information, apparatus, product, or process disclosed, or represents that its use would not infringe privately owned rights. Reference herein to any specific commercial product, process, or service by trade name, trademark, manufacturer, or otherwise does not necessarily constitute or imply its endorsement, recommendation, or favoring by the United States Government or any agency thereof. The views and opinions of authors expressed herein do not necessarily state or reflect those of the United States Government or any agency thereof. 


\section{DISCLAIMER}

Portions of this document may be illegible in electronic image products. Images are produced from the best available original document. 


\section{Q}

\section{Rockwell International}

\section{Rockwell Hanford Operations \\ Energy Systems Group \\ Richland, WA 99352}

PRELIMINARY REPORT

This report contains information of a prelıminary nature it is subject to revision or correction and therefore does not represent a final report. It was prepared primarlly for internal use within Rockwell Hanford Operations Any expressed views and opınions are those of the author and not necessarily of the Company.

\section{DISCLAIMER}

This report was prepared as an account of work sponsored by an agency of the United States Government. Neither the United States Government nor any agency thereof, nor any of their employees, makes any warranty, express or implied, or assumes any legal liability or responsıbility for the accuracy, completeness, or usefulness of any information, apparatus, product, or process disciosed, or represents that its use would not infringe privately owned rights. Reference hereın to any specific commercial product, process, or service by trade name, trademark, manufacturer, or otherwise, does not necessarily constitute or imply its endorsement, recommendation, or favoring by the United States Government or any agency thereof. The views and opınions of authors expressed herein do not necessarıly state or reflect those of the United States Government or any agency thereof. 
RHO-BWI-LD-23

THE FUNCTIONS OF AN

ENGINEERED BARRIER SYSTEM

FOR A NUCLEAR WASTE REPOSITORY IN BASALT

\author{
W. E. Coons \\ E. L. Moore \\ M. J. Smith \\ J. D. Kaser \\ Engineered Barriers Group \\ Basalt Waste Isolation Project
}

This book was prepared as an account of work sponsored by an agency of the Uni ted States Governmen Nerther the United States Government nor any dqency thereot nor any of therr emoloyees makes any

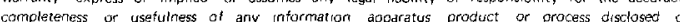
represents that tis use would not infringe privalely owned rights Referencice herent to any commercial protuct process, or service by trade name trademark manufacturer or otherwise do not necessarty constitute or imply its endorsoment recommencation or tavor nig by the $U$ do States Government or any agency thereo the views and opinions of authors expressed here $n$ do no

January 1980

Rockwell International

Rockwell Hanford Operations

Energy Systems Group

Richland, Washington 99352 


\section{A B S T R A C T}

Defined in this document are the functions of components selected for an engineered barrier system for a nuclear waste repository in basalt. The definitions provide a focal point for barrier material research and development by delineating the purpose and operative lifetime of each component of the engineered system. A five-component system (comprised of waste form, canister, buffer, overpack, and tailored backfili) is discussed in terms of effective operation throughout the course of repository history, recognizing that the emplacement environment changes with time. While components of the system are mutually supporting, redundancy is provided by subsystems of physical and chemical barriers which act in concert with the geology to provide a formidable barmier to transport of hazardous materials to the biosphere. The operating philosophy of the conceptual engineered barrier system is clarified by examples pertinent to storage in basalt, and a technical approach to barrier design and material selection is proposed. A method for system validation and qualification is also included which considers performance criteria proposed by external agencies in conjunction with site-specific models and risk assessment to define acceptable levels of system performance. 


\section{CONTENTS}

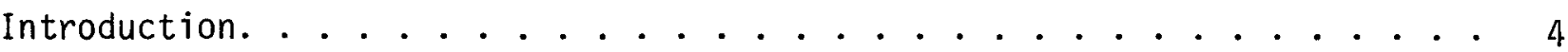

Historical. ..................... . . 4

Purpose ................... . . 5

General Design Goal ................ 5

The Engineered Barrier System . . . . . . . . . . . . . 7

System Description and 0peration. ............. 7

System Criteria ................... . . 11

Functional Requirements................. 13

The Engineered Barrier System . . . . . . . . . . . 13

Function. ................... . . . 13

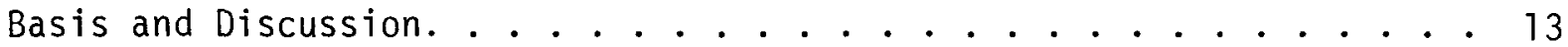

The Components of the Engineered Barrier System . . . . . . . . . . 13

Waste Form. . . . . . . . . . . . . . . . . . . 13

Canister. . . . . . . . . . . . . . . . 14

Buffer. . . . . . . . . . . . . . . 16

Overpack. ...................... 16

Tailored Backfill ....................... 17

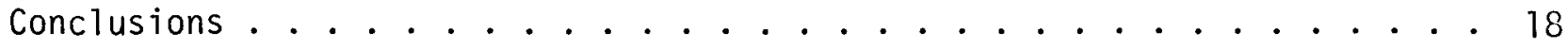

Appendix - Technical Approach to Design . . . . . . . . . 19

References........................ 25

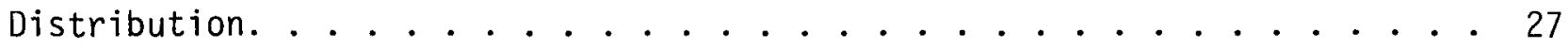

Tables:

1 Barrier Function Versus Time ............... 10

2 Applicable Criteria That May Affect Waste Package/

Engineered Barrier Design . . . . . . . . . . 12

Figures:

1 Screening Process for an Acceptable Engineered Barrier System. . . . 6

2 Engineered Barrier System Emplacement Concept. . . . . . . . 8

3 Typical Engineered Barrier System Emplacement Concept. . . . . . . 9

A-1 Required Components of an Engineered Barrier System as a Function

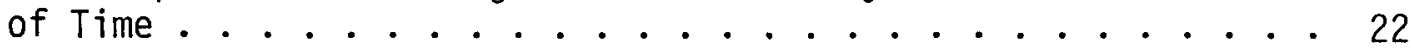


RHO-BWI-LD-23

INTRODUCTION

HISTORICAL

Until recently, the United States' philosophy for geologic storage of highlevel nuclear wastes placed great emphasis on the host rock acting as the primary barrier for the containment of radionuclides (Batch and Heath, 1979). Recognizing the complexity of predicting long-term stability of geologic formations and the resultant uncertainty in their functioning as long-term barriers to radionuclide migration, the United States has (since 1977) adopted a multiple barriers approach to high-level nuclear waste storage and disposal. This approach involves the concept of engineered barriers (i.e., waste form, canister, buffer, overpack, backfill, borehole plugs, etc.) acting in concert with the natural barriers (geologic strata, distance to biosphere, etc.) in a sufficiently conservative manner to prevent unacceptable release of radionuclides to the biosphere. Such an approach has been widely accepted and endorsed by both United States' government agencies and the general scientific community, which have stated that:

"Multiple and redundant components (engineered barriers) to isolate waste or substantially inhibit radionuclide movement are called for to compensate for uncertainties in assessing the long-term performance (of the) repository system." (NRC, 1979a)

"A systems approach should be used to select the geologic environment, repository site, and waste form. A systems approach recognizes that, over thousands of years, the fate of radionuclides in a repository will be determined by the natural geologic environment, by the physical and chemical properties of the medium chosen for waste emplacement, by the waste form itself and other engineered barriers. If carefully selected, these factors can and should provide multiple, and to some extent independent, natural and engineered barriers to the release of radionuclides to the biosphere." (IRG, 1979)

"With the expansion of effort and proliferation of viewpoints came the realization that total isolation in the immediate waste repository probably cannot be guaranteed, and the recognition that a series of barriers - both engineered and natural - to waste migration could offer the level of protection needed to compensate for the uncertainties in predicting long-term waste isolation." (DOE and USGS, 1979)

"Protection against possible release of radionuclides goes beyond the two levels of containment provided by the solid (waste) form itself. A satisfactory method for disposing of high-level nuclear wastes will be one that uses a sequence of multiple barriers..." (NAE and NAS, 1979)

"...the safe disposal of nuclear waste in a mined geologic repository is an acceptable approach. This disposal method is based on a series of engineered and naturally occurring barriers to the environment (biosphere)..." (ANS, 1979) 
RHO-BWI-LD-23

PURPOSE

While the concept of an engineered barrier system designed to provide redundancy in waste isolation has received firm support, the function of such a system has been described only in general terms (Westerman, 1979; DOE and USGS, 1979). A more detailed functional description is necessary to act as the basis for continued research supporting engineered barrier development for a nuclear waste repository in basalt. The primary purpose of this document, therefore, is to define those functions in greater detail. A concise statement of the function of each barrier in a conceptual system is given, accompanied by a brief discussion intended to convey the basis for the statement and to give examples of candidate materials which might be selected to meet the engineered barrier design goal. As an introduction to the discussion, a conceptual engineered barrier system is defined, and the operating philosophy is briefly discussed. Proposed criteria which will influence the design of the engineered barrier system are identified.

The remainder of the document is an appendix which has been separated from the other sections to prevent its overshadowing the primary purpose of this report. Described in the appendix are a possible approach to the design of engineered barrier systems, the philosophy behind barrier system design as employed by the Basalt Waste Isolation Project (BWIP), and a brief discussion of possible material selection and system validation techniques. Because a methodology for determining system performance requirements, selecting candidate components and materials, and verifying system performance are all summarized, the appendix may be especially helpful to the reader.

GENERAL DESIGN GOAL

The engineered barrier system must be a practical system designed to meet the need for protection of public health and safety. It must meet this need in a cost-effective manner within the envelope of performance criteria presently being proposed and promulgated by cognizant federal agencies. These criteria are needed, but they should not motivate a research and development effort that pursues the development of ideal engineered barrier systems and ignores the cost of inordinately long development programs.

It is the goal of the BWIP to develop acceptable engineered barrier systems which are waste-form and site specific, and which are cost effective and functionally acceptable for emplacement in a repository located in basalt (i.e., site specific). In order for the engineered barrier system to be usable in such a repository, it will be developed in accordance with project milestones. These goals are to be accomplished through a graduated screening process that progresses from selection and evaluation of barrier components to final selection of a reference barrier system for each waste form identified for use in a repository in basalt. Final refinement and confirmation of barrier system acceptability are to be accomplished prior to repository operation. The selection process is outlined in Figure 1. 
STEP I: DEFINE BARRIER SYSTEM CRITERIA

- DEFINE EXISTING CRITERIA

- QUANTIFY BARRIER SYSTEM CRITERIA

STEP II: GENERATE AND EVALUATE ALTERNATIVE SYSTEM CONCEPTS

- GENERATE ALTERNATIVE CONCEPTS

- DEFINE REQUIRED DESIGN AND PERFORMANCE INFORMATION

- DEFINE SYSTEM COMPONENT FUNCTIONS

- EVALUATE ALTERNATIVE CONCEPTS BASED ON TECHNICAL FEASIBILITY, RELIABILITY, AND COST

STEP III: SELECT AND DEVELOP REFERENCE BARRIER SYSTEM

- GATHER NECESSARY DESIGN AND PERFORMANCE DATA

- SELECT CANDIDATE MATERIALS

- DESIGN REFERENCE SYSTEM

STEP IV: QUALIFY REFERENCE BARRIER SYSTEM

- TEST COMPONENTS

- TEST SYSTEM

- CONFIRM SYSTEM PERFORMANCE WITH PREDICTIVE MODEL

- UPDATE SYSTEM DESIGN

FIGURE 1. Screening Process for an

Acceptable Engineered Barrier System. 
RHO-BWI-LD-23

THE ENGINEERED BARRIER SYSTEM

\section{SYSTEM DESCRIPTION AND OPERATION}

Technology development is not sufficiently advanced to permit at the present time a precise engineered barrier system design description for a nuclear waste repository in basalt. This must await an understanding of the chemical interactions occurring among the basalt, groundwater, and waste form and other components of the engineered barrier system within the repository environment. However, for the purpose of this report, a five-component barrier system has been selected and is depicted in Figure 2. These components encompass the several types that may be required for an effective barrier system. Also shown in Figure 2 are a grouted region and a retrieval sleeve. The grouted region represents one means of stabilizing the basalt disturbed during emplacement hole drilling. The grout would exhibit some water-retardant properties, but is not considered an engineered barrier component for the present discussion. The use of the retrieval sleeve reflects the need for a means of facilitating the retrieval of the waste, if required, during the operational period of the repository. It would be designed for short-term service and would not constitute a long-term barrier to water intrusion; hence, it is also not considered a barrier component for the present discussion.

Depicted in Figure 3 is one potential scheme for emplacing the engineered barrier system in a repository in basalt. Also illustrated is the merger of the engineered and natural barrier systems to form the multiple barrier system required for effective nuclear waste isolation.

The operating philosophy for the engineered barrier system depicted in Figure 2 can best be described in terms of the repository history, which can be divided into two fundamental periods based on the prevailing conditions at the time. The early history (e.g., 1,000 years) is defined as the thermal period, and is that interval of time during which the ambient geothermal gradient is perturbed by the heat produced by radionuclide decay and includes the portion of time before repository closure when the repository is under institutional control. Late repository history is the period of geologic control and is defined as the interval of time after the thermal period when geologic conditions have returned to a static, natural, thermal condition and prior to decay of radionuclides to innocuous levels. The different environmental conditions existing during these two time periods give rise to separate problems, different engineered barrier functions, and different materials requirements. The engineered barrier functions versus the repository operating history are tabluated in Table 1. The functions of the geology (basalt) are included to show the relationship between the engineered barriers and the natural barriers.

As noted in Table 1, the waste form and canister function prior to emplacement in the repository. The waste form acts to retain the radionuclides, while the canister provides physical support and protection for the waste form during handling and transportation. Thereafter, for the life of the repository, the waste form continues to function in the same manner, while the role of the 


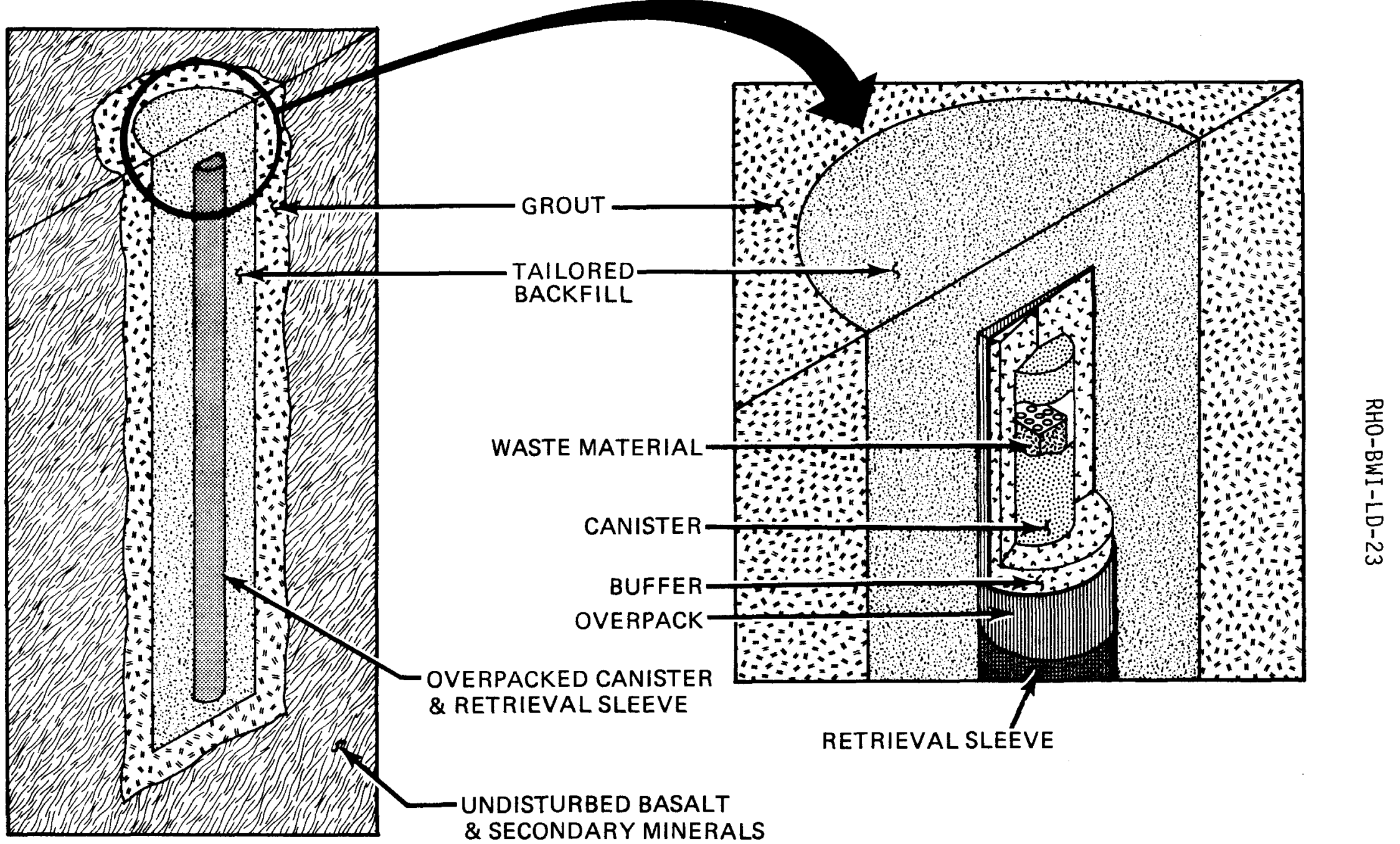

msEB 1/80 rev

FIGURE 2. Engineered Barrier System Emplacement Concept. 


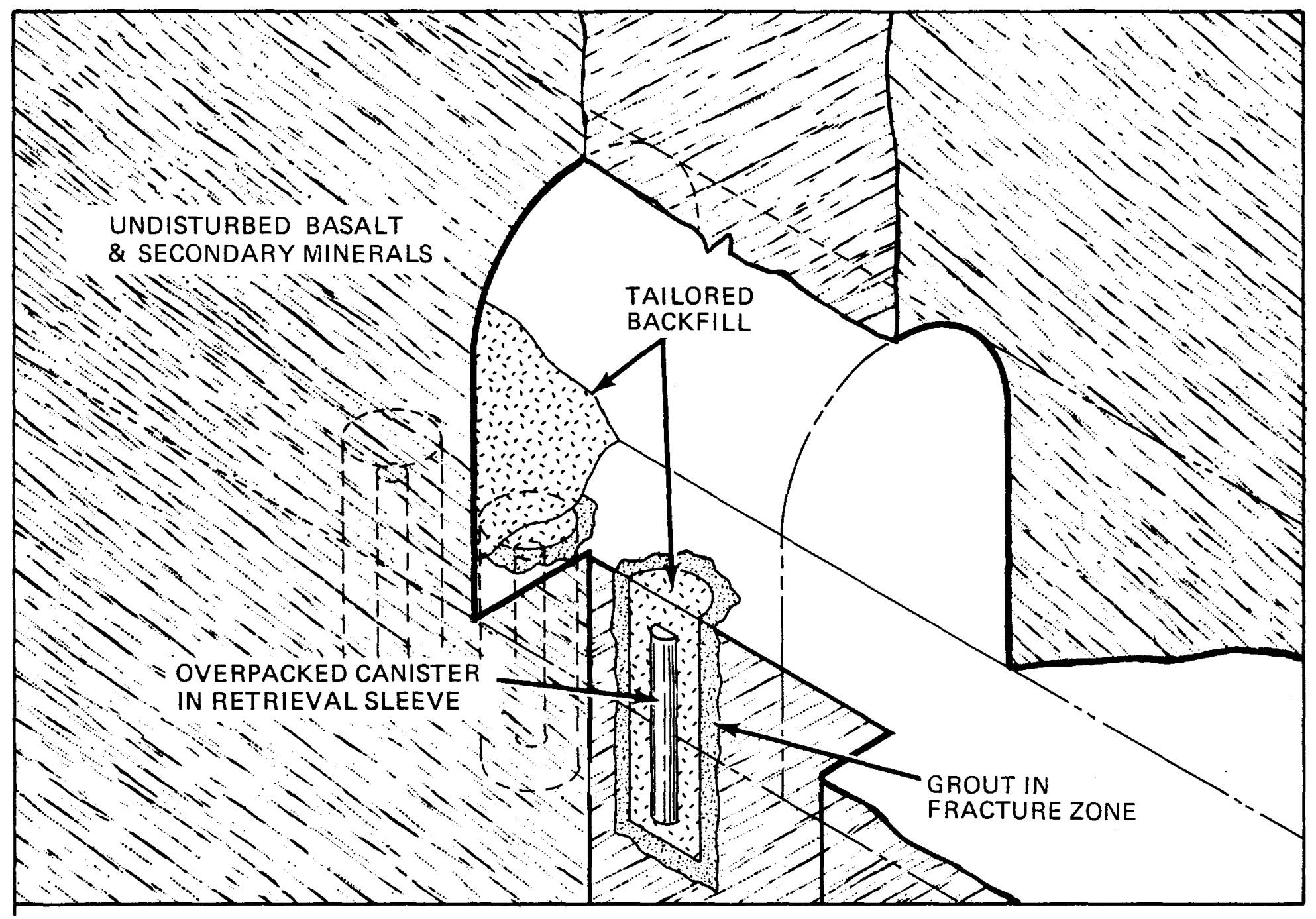

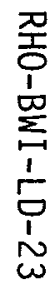

FIGURE 3. Typical Engineered Barrier System Emplacement Concept. 
TABLE 1. Barrier Function Versus Time.

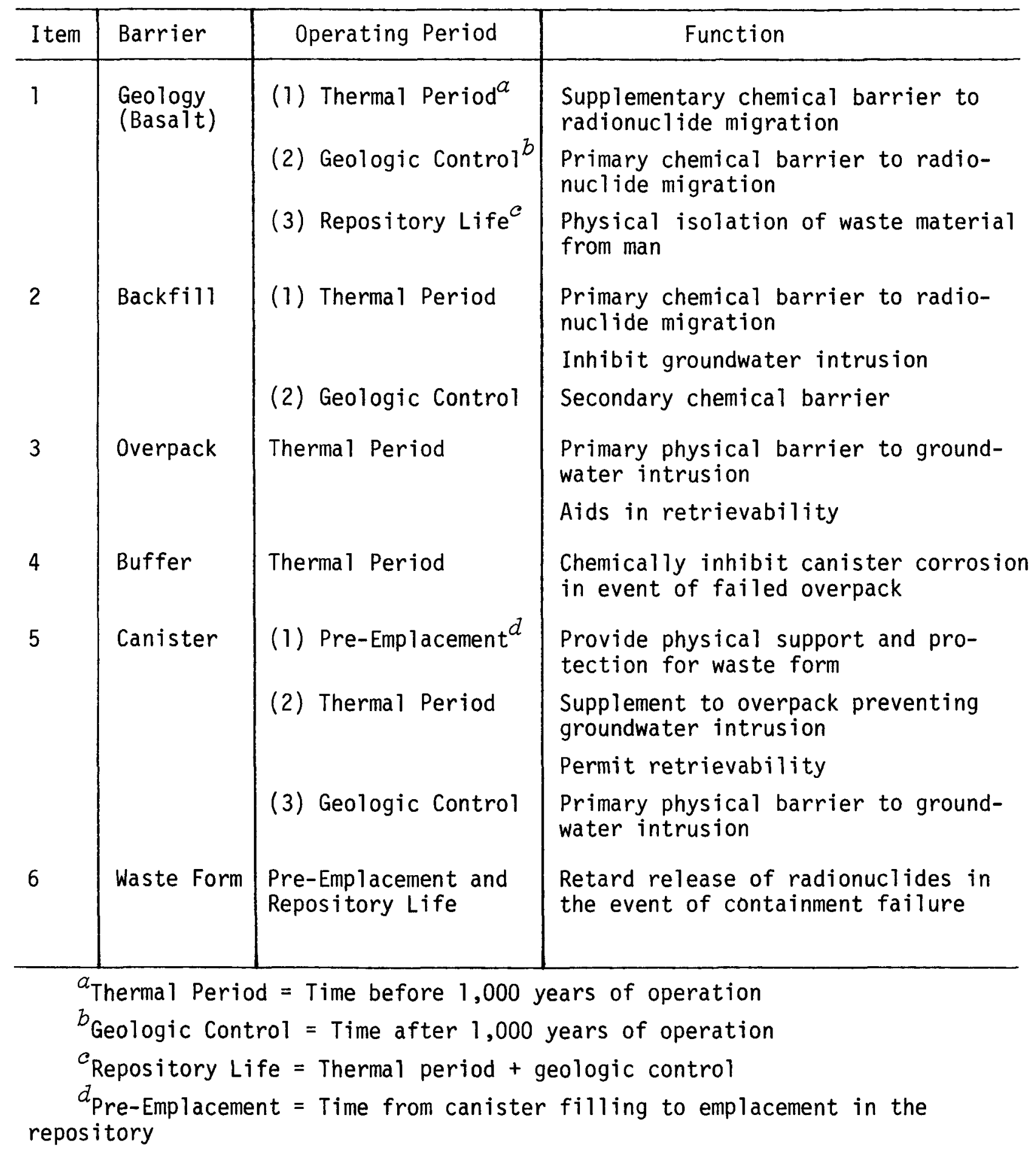


canister and remaining engineered barriers varies with the operating period. Also, during the repository operating period, the geology prevents access of the waste form to man.

During the thermal period, the canister, overpack, and backfill act to retard or prevent groundwater intrusion to the waste form, with the overpack functioning as the primary physical barrier and the backfill and canister functioning in supplementary roles. In the event of a premature failure of the overpack, the buffer acts to modify (Eh and $\mathrm{pH}$ control) the groundwater chemistry to decrease corrosion of the canister. Should the canister also become breached, the tailored backfill then functions as the primary chemical barrier to radionuclide migration, with the basalt functioning in a redundant role as a chemical barrier. During the early part of the thermal period (the period of retrievability), the overpack and canister also allow retrieval if such an operation is required.

Canisters which have survived the thermal period will continue to function as primary physical barriers to water intrusion during the period of geologic control. As the canisters fail and groundwater reacts with the waste form, the basalt will function as the primary chemical barrier and the backfill will function as a secondary chemical barrier to radionuclide migration to the bisophere.

The functions of the conceptualized engineered barrier system and each of its components, together with examples of candidate materials, are discussed in greater detail in the section entitled Functional Requirements.

\section{SYSTEM CRITERIA}

The engineered barrier system must be designed to meet certain criteria to be acceptable from the viewpoints of health and safety and protection of the environment. The need for such criteria was recognized early in the National Waste Terminal Storage (NWTS) Program before the advent of the engineered barrier concept as it is known today. Early criteria development activities addressed the waste form and canister which comprised the waste package. Draft acceptance criteria were written which identified the constraints the waste package must meet to be compatible with handling and transportation facilities, as well as the geologic repository they were to support (Moore and Calmus, 1978). The draft waste package acceptance criteria were based on the then-perceived restrictions on physical dimensions, weight, shape, thermal power, etc., and were needed to support conceptual design activities associated with a geologic repository to be located in a salt formation. These criteria were, by necessity, semiquantitative, since much of the data influencing waste package design were yet to be developed.

The lack of an adequate data base motivated the Office of Nuclear Waste Isolation (ONWI), as coordinator of the NWTS Program, to broaden criteria development activities. Under their direction, qualitative statements are being prepared which define the general program policies and criteria intended to provide direction for all NWTS Program efforts. The ONWI waste package criteria 
are generic, and it is their intent that site-specific data be developed by each repository program to permit the development of waste package (engineered barrier system) acceptance and design criteria.

In addition to the draft criteria being developed for the U.S. Department of Energy by ONWI, other federal agencies have proposed criteria which will influence the disposal of radioactive waste (NRC, 1979a, 1979b; EPA, 1979). To illustrate the breadth of the criteria that will affect engineered barrier system design, those applicable are tabulated in Table 2.

TABLE 2. Applicable Criteria That May Affect Waste Package/Engineered Barrier Design.

\begin{tabular}{|c|c|}
\hline Source & Requirements \\
\hline $\begin{array}{l}10 \text { CFR 50, } \\
\text { Appendix F (1979) }\end{array}$ & $\begin{array}{l}\text { Liquid high-level waste must be solidified within } 5 \text { years } \\
\text { of its generation and transferred to a federal repository } \\
\text { within } 10 \text { years of its generation. The solid waste must } \\
\text { be chemically, radiolytically, and thermally stable to } \\
\text { prevent excessive pressurization of the canister from } \\
\text { the canning to } 90 \text { days after receipt at the federal } \\
\text { repository }\end{array}$ \\
\hline $\begin{array}{l}10 \text { CFR } 60 \\
\text { Subpart E, } \\
\text { Proposed Draft } 7\end{array}$ & $\begin{array}{l}\text { Engineered barrier system to provide reasonable assur- } \\
\text { ance of containment for at least the first } 1,000 \text { years } \\
\text { after decommissioning }\end{array}$ \\
\hline & $\begin{array}{l}\text { Maintain retrievability option for the duration of the } \\
\text { operational period plus } 50 \text { years }\end{array}$ \\
\hline $\begin{array}{l}40 \text { CFR } 191 \\
\text { Subpart B, } \\
\text { Proposed Draft } 7 \\
\text { (November 1979) }\end{array}$ & $\begin{array}{l}\text { Requires a system of multiple passive barriers with } \\
\text { each barrier designed to isolate the waste } \\
\text { Requires design to permit waste recovery in future years } \\
\text { Must be designed to deter unintentional intrusion by man } \\
\text { Requires zero release from the engineered barrier system } \\
\text { for first 1,000 years. From } 1,000 \text { to } 10,000 \text { years, re- } \\
\text { lease should be limited to that associated with } 1 \text { death }\end{array}$ \\
\hline
\end{tabular}


RHO-BWI-LD-23

FUNCTIONAL REQUIREMENTS

THE ENGINEERED BARRIER SYSTEM

Function

To limit release of hazardous materials associated with nuclear waste to levels below established limits by means of an integrated system of physical and chemical barriers acting in concert with the geology.

Basis and Discussion

In the section entitled System Description and Operation, the engineered barrier system is described as a complementary, multi-component array which acts to inhibit hazardous release of commercial nuclear waste materials. A sequence of engineered barriers is required to maximize the safety of subsurface storage of nuclear waste even in the event of a worst credible repository failure; however, the components are not completely redundant to each other and cannot be designed to be completely redundant. Rather, some components are supportive to others, enhancing the likelihood of reliable system performance.

There are two subsystems within the engineered barrier system. Physical containment of the hazardous material is provided by the canister and overpack, and is enhanced by the buffer. Redundant chemical containment is provided by a backfill specifically tailored for the waste form and the surrounding basalt formations of a nuclear waste repository. This system will operate to restrict release in the event of failure of the physical barriers. Because the containment mechanisms of the two systems are so different (i.e., physical isolation as opposed to chemical reaction), it is very unlikely that both systems could be rendered inoperative by a single, worst-case accident.

As conceived, the engineered barrier system must be tailored to meet the needs imposed by waste form leachability (which requires it to be waste-form specific), while simultaneously maintaining compatibility with the geologic environment (which requires it to be site specific). These criteria are necessary to ensure that the system adequately prevents excessive release of hazardous material to the bisophere. To perform this function, it is required that each system be specifically designed to meet the needs of each repository and each waste form. A final design constraint is that barrier components should not interact so as to diminish performance of either subsystem.

THE COMPONENTS OF THE ENGINEERED BARRIER SYSTEM

Waste Form

Function. To immobilize radionuclides associated with muclear fuels by containment as part of a solid, such as glass or cercomic. 
Basis and Discussion. The waste form is a solid, such as glass or ceramic, which incorporates the hazardous materials from nuclear fuel thereby facilitating handling, storage, and transportation. Several waste forms have been proposed, but all fall into one of three categories: (1) spent fuel; (2) glass; and (3) tailored ceramics. Each of these forms has its virtue, being favored for either technical, economic, or non-proliferation reasons. It is the position of the BWIP that an acceptable system can be designed for any given waste form, but that the waste-form choice will impact the complexity, hence the cost, feasibility, and size of a subsurface repository.

As an example of a waste form that may require greater reliance on an engineered barrier system, consider spent fuel which is the waste form specified by national policy and is the waste form receiving most attention by BWIP. Its merits include high waste loading and no fabrication expense. However, preliminary evidence indicates a possible susceptibility of some components to hydrothermal leaching--most notably cesium, strontium, and rubidium (Johnson, 1977; Scheetz, et a1., 1979). Therefore, in order to conform to draft regulatory criteria (NRC, 1979a), it would be necessary to engineer a system which protects or mitigates chemical corrosion of the waste form.

There are two ways to inhibit dispersal of radionuclides from spent fuel; prevent access of water to the waste or remove dissolved waste components from contaminated groundwater by reaction with a backfill material. Redundancy requires the operation of both mechanisms and will result in the need for a more sophisticated canister/overpack/backfill engineered barrier system which, in turn, will affect the cost and size of repository construction.

In contrast, consider the prospect of a highly leach-resistant waste form. By itself, it may be an effective barrier to radionuclide release, with the potential to function acceptably from emplacement to beyond the thermal period of a repository. An engineered barrier system based on such a waste form may consist of only a canister plus backfill. However, additional cost will be incurred by fabrication and these costs may be considerable if the waste form is not sufficiently flexible to accommodate the variations in composition inherent to a reprocessed waste stream.

In summary, the waste form is an integral part of the engineered barrier system. While an acceptable system can be designed regardless of the waste form selected, waste-form choice will directly affect the size and cost of both the repository and associated barrier system. It is the plan of BWIP to develop a basalt-specific engineered barrier system for spent fuel which is the waste form specified by national policy. Secondary consideration is being given to basaltspecific systems for alternate waste forms (e.g., borosilicate glass, Supercalcine, and Synroc) as a contingency in the event a decision to reprocess spent fuel is made.

\section{Canister}

Function. To provide physical support and protection for the waste form during solidification, handling, and shipping and to act as the primary physical barrier to water intrusion following the thermal period in the repository. 
Basis and Discussion. Since the inception of the national waste management effort, the waste canister has been viewed as a primary containment vessel designed to safely contain solidified waste: (1) during solidification and a period of interim storage; (2) during handling and shipping; and (3) for a period of time after disposal in a geologic repository. The canister may contain a filler to keep the canister from collapsing under the pressures expected in a closed repository. The canister design life has been extended: from the earlier requirement of 10 years' interim storage at the reprocessing facility plus 90 days after geologic disposal (NRC, 1979b); to the 100-year requirement for interim storage in a retrievable surface storage facility (ARHCO, 1974); and now to the present multi-hundred-year requirement for geologic disposal (NRC, 1979a). With each incremental increase in design life requirements, the need for increased level of support for materials evaluation studies has been recognized.

Today the canister must bear a significantly greater burden of geologic waste isolation. The "head end" activities (design and fabrication quality assurance/ quality control requirements, waste management system facility licensing requirements, transportation requirements, waste solidification processing requirements, possible requirements for a period of interim storage in water, etc.) plus the longevity requirements all have substantial impact on the material performance requirements and the need for mutually complementary engineered barriers to meet the requirements for waste isolation become obvious.

As an example, the design life requirements for the waste canister may extend beyond the thermal period of the repository and well into the period of geologic containment (>1,000 years). During the thermal period, principal reliance for prevention of groundwater intrusion will be on the backfill and overpack, thus protecting the canister and enabling it to function at a later time. Following the thermal period and assuming failure of the overpack, the groundwater will be more benign (lower temperature and higher pH) and will be anoxic due to the reducing capability of the basalt, and corrosion rates will be much lower.

The list of candidate materials suitable for an anoxic environment may contain titanium-base, iron-base, nickel-base, and copper-base alloys. Material evaluation studies incorporating these alloy systems have yielded results which are quantitatively applicable to the choice of canister materials for use in a repository in basalt. Braithwaite and Molecke (1979) have conducted corrosion studies to identify canister materials suitable for use in bedded salt repositories and seabed sediments. Three alloys (Ticode 12, Hastelloy C-276, and 90-10 Cupronicke1) were identified for further study. Inconel 625, Incoloy 825, and lead were considered as alternative candidate metals. Other studies by Shannon (1978) yielded results similar to the Braithwaite and Molecke (1979) studies. Hastelloy C-276, Inconel 625, Inconel 600, Incoloy 825, and several titanium-base alloys were resistant to $250^{\circ} \mathrm{C}$ oxygen-free brine solutions.

Material corrosion in low-ionic-strength groundwaters typical of a repository in basalt is anticipated to be less in brines or seawater; hence, the abovenoted alloys can also be considered as candidate materials suitable for service in basalt environments. 


\section{Buffer}

Function. To prolong canister life in the event of overpack failure by producing a chemical environment less conducive to canister corrosion and to improve thermal conductivity between the canister and overpack.

Basis and Discussion. The buffer is a mechanical mixture of specialized components designed to extend the life of a canister which otherwise might not survive through the thermal period. Emplaced between the canister and overpack, the buffer operates in the event of minor overpack failure and modifies or controls the local environment.

For example, assume a rupture in the overpack that is small but sufficient to permit entry of groundwater. During the thermal period, it is possible that the groundwater $\mathrm{pH}$ may be as low as 4 due to hydrothermal reactions between the host rock and the groundwater. Under the oxygen fugacity imposed by geologic systems, and with acid solutions, it is likely that an iron-based canister would corrode rapidly. However, given an environment where groundwater flow is restricted, a material which (1) absorbs water, (2) raises $\mathrm{pH}$, and (3) depresses oxygen fugacity will greatly extend canister life. Once the canister survives the thermal period, it will need minimal support from the buffer because conditions will have returned to high pH and low temperature. Under these conditions, even an iron-based canister is resistant to corrosion.

Candidate buffer materials must be compatible with the canister/overpack assembly and must be chosen to moderate conditions imposed by the geology which are unfavorable to canister life. Therefore, candidate buffer materials are necessarily specific to the canister/overpack and to the repository geology. For the case of an iron-based canister in a basalt environment, candidate materials include graphite; powdered iron, aluminum, and/or titanium; swelling clays, lime, or carbonates. These materials have been chosen for moderation of oxygen fugacity (graphite, powdered iron, and/or titanium), or groundwater $\mathrm{pH}$ (lime, carbonates, aluminum), or because of their ability to inhibit groundwater intrusion (aluminum, swelling clays). In addition, graphite and metals are good thermal conductors and can be expected to aid heat transport out of the waste package.

It is unlikely that the buffer will be composed entirely of a single material given the several purposes for which it is intended. It is more likely that the buffer will be a composite material which is sized and pre-formed to fill most of the volume between the canister and overpack.

\section{Overpack}

Function. To act as a barrier to the intrusion of groundwater through the thermal period of the repository and to provide a means for retrievability of the waste through the retrieval period.

Basis and Discussion. The overpack will be a highly corrosion-resistant metal or ceramic material. Because of shipping weight and size restrictions, the buffer and overpack will likely be added to the waste canister in packaging 
facilities located at the repository. It is anticipated that fabrication specifications will not be as restrictive as those for the canister because it will not function as a primary barrier for waste containment, and it will not be transported across the country. However, it must be designed with sufficient strength to allow handling and permit retrieval should the need arise during the retrieval period.

The overpack (whose principal function is containment) will be designed to perform this function from its emplacement through the thermal period (zero to 21,000 years) of the repository. During this period, the groundwater will tend to be more corrosive due to the higher temperature and possibly lower pH. For the first 100 years, during the period of institutional control, the repository will be open. Groundwater will be accessible to oxygen, and oxidizing conditions may prevail during a portion of this segment of the thermal period. Gradually, the crushed basalt, as a component of the backfill, will promote anoxic conditions and alloys suitable for service in both oxidizing and anoxic environments would be considered candidates for overpacks. Ticode 12, a titanium-base alloy, is currently a prime candidate for overpacks by the BWIP. It requires a source of oxygen to preserve its passive oxide coating. Under anoxic conditions, the source of oxygen is supplied by the reduction of water by titanium metal.

Other candidates being considered for service in both environments are the nickel-base alloys, Hastelloy C-276, Inconel 625, and Incoloy 825. The copperbase alloy, 90-10 Cupronickel, exhibits unacceptable corrosion resistance in oxidizing environments; thus it is only useful in anoxic environments. However, further testing under environmental conditions expected in a repository in basalt may prove them to be suitable candidates for overpack fabrication.

\section{Tailored Backfill}

Function. To provide thermal continuity between the overpack and the wall rock, aid emplacement (i.e., alignment) of the canister/overpack assemblage, and act as the primary chemical barrier to radionuclide migration. The backfill will also lend stmuctural support to the repository and inhibit access of water to the container.

Basis and Discussion. The backfill is a crushed material which will be packed around the canister and used to fill the repository and borehole excavations. Rather than simply filling the hole and/or repository with previously mined rock, it may be preferable to tailor the material to act as an engineered barrier.

It is conceived that the backfill will act as a primary barrier to groundwater intrusion. This requires that the material be easily compacted and/or that it swells to absorb pore volume. It is imperative to design the backfill to promote reaction with hazardous materials that might disperse from a failed canister/overpack system. Thus, materials which absorb cesium, rubidium, strontium, and transuranic elements could be prerequisites. 
A final consideration is that the backfill materials must have moderate thermal stability. Although the backfill is intended to operate throughout the life of the repository, the most likely period for failure of physical containment is during the thermal period. Therefore, it is critical that the backfill be both stable and operative between temperatures of $65^{\circ} \mathrm{C}$ and $300^{\circ} \mathrm{C}$. While both temporary sorption and permanent retention are desirable qualities, an idealized backfill will react irreversibly with waste components, permanently trapping them in a crystalline framework.

The backfill possibly may be compacted and pre-formed into suitable shapes before placement in the boreholes. This procedure may simplify placement of canisters and also may facilitate canister retrieval. Pre-formed backfills acting as sleeves should aid in canister placement. This sleeve then becomes the chemical barrier to radionuclide release and a barrier to groundwater intrusion. Materials being considered by the BWIP as candidate components of the backfill include swelling clays (to retard groundwater intrusion), crushed basalt and sodium feldspars (reactive extraction of cesium, rubidium, and strontium), and zeolites, titanates, and bornite (sorb radionuclides).

\section{CONCLUSIONS}

An individual engineered barrier system as part of a total repository multiple barrier system should be designed for each credible waste form and for a specific geologic environment because of the compatibility requirements. The engineered barrier system is composed of two subsystems; physical barriers and chemical barriers. These two parts are redundant to each other, but the individual components of each part are mutually supportive, which enhances barrier system reliability and extends barrier system life. The various components of the total system should be designed to operate in a complementary manner during each period of repository history (although effectiveness beyond intended barrier life is not to be discouraged). Individual barrier materials will be chosen so as not to impair the effectiveness of other barrier materials. Material selection procedures that are both objective and well documented will result in an integrated system capable of limiting the release of hazardous waste materials to acceptable limits. 
RHO-BWI-LD-23

APPENDIX

TECHNICAL APPROACH TO DESIGN 
RHO-BWI-LD-23

APPENDIX

TECHNICAL APPROACH TO DESIGN

An engineered barrier system must be designed to be compatible with and complementary to the geologic environment over a range of expected conditions and operate effectively with the geologic components of the multiple barrier system to prevent dispersal of radionuclides in the event of a worst-credible repository failure. Given these requirements, it is likely that a barrier system will be tailored to meet the needs of each waste form utilized in a site-specific geologic setting. The BWIP has no program for waste-form development, but anticipates designing an engineered barrier system for any credible waste form which might be emplaced in a repository in basalt. At present, the candidate waste form is spent fuel; however, alternative waste forms are being considered in engineered barrier system development as backup to prevent time lag in the event of a change in national policy.

The following discussion will focus on an approach to systems design. This approach is presently being considered by the BWIP and is in the development stage; it is tentatively offered as a screening technique for system construction given a limited data base. The design process includes techniques for: (1) determining system performance requirements; (2) selecting barrier components; and (3) validating qualified barrier systems. The remainder of this appendix is a discussion of these procedures, giving examples to aid understanding.

\section{BARRIER SELECTION}

The first step in the procedure for relating engineered barrier components and materials is to define the necessary barrier components. The nature and number of barrier components are dictated by the specific waste form chosen and the geologic environment controlling system stability. It is important to consider the temporal nature of the repository and the multitude of environments to which a barrier will be subjected. The barrier system must then be matched with the job and the conditions expected for its operating life. For the purpose of illustration, consider storage of spent fuel elements in basalt. In tests using simulated spent fuel, some components of the waste form appear to be leachable if exposed to heated water (Scheetz, et al., 1979). It also appears that the leachable components are very reactive to sodium feldspar. This information regarding the reactivity of spent fuel leads to several conclusions:

(1) Spent fuel must be isolated from groundwater.

(2) A backfill will likely be required to guard against waste dispersal in the event of container failure and groundwater incursion. 
(3) A major component of the backfill will probably be sodium feldspar, which will immobilize cesium by reaction to pollucite and will also fix strontium and rubidium.

(4) Physical containment of the fuel may require site-specific overpacking.

\section{REPOSITORY CONDITIONS AND MATERIAL SELECTION}

In order to compose a preliminary list of barrier materials, it is first necessary to consider normal conditions in an operating repository. These conditions may be estimated by modeling (e.g., temperature contouring), experimentation (e.g., hydrothermal solution composition), and/or field measurements (e.g., ambient groundwater compositions and temperatures).

Some of these conditions depend on repository design, while others are intrinsic to geologic storage. For instance, spent fuel stored according to the preconceptual design configuration for a repository in basalt at Hanford is calculated to raise the surrounding rock to a temperature of $250^{\circ} \mathrm{C}$ at peak thermal output (Hardy and Hocking, 1978). However, the maximum temperature could be reduced by increased canister spacing or through decreased waste loading. In contrast, groundwater reaction with silicate glass generates acid and wi11 depress solution pH (Bischoff and Dickson, 1975; Barnes and Scheetz, 1979). This chemical process will occur as long as magnesium-rich clay is formed as a reaction product. It is important to distinguish those parameters which are flexible in order to make informed decisions later in the material-selection process. Presently at Hanford, the parameters in an operating repository in basalt considered to affect barrier material selection include:

Temperature $65^{\circ}-250^{\circ} \mathrm{C}$

Pressure 100-300 bars

Oxygen fugacity $\mathrm{Ni}-\mathrm{NiO}$ to $\mathrm{Fe}_{3} \mathrm{O}_{4}-\mathrm{Fe}_{2} \mathrm{O}_{3}$ control

Groundwater pH 4.0-10.1

Presence of aqueous complexing agents $\mathrm{Cl}^{-}, \mathrm{F}^{-}, \mathrm{SO}_{4}^{-}$.

Reflecting on the range of these parameters, the wisdom of considering engineered barriers as an integrated system becomes clear. It is unlikely that a single encapsulation material can be depended on to survive through all repository conditions. It seems more prudent to design a set of barriers with each component designed to perform a specific function and operate during a specific period of repository life. Illustrated in Figure A-1 are the components of an engineered barrier system at two different times in repository history. The examples of radionuclides of concern in different time periods shown in Figure A-1 will be discussed in a later document. 


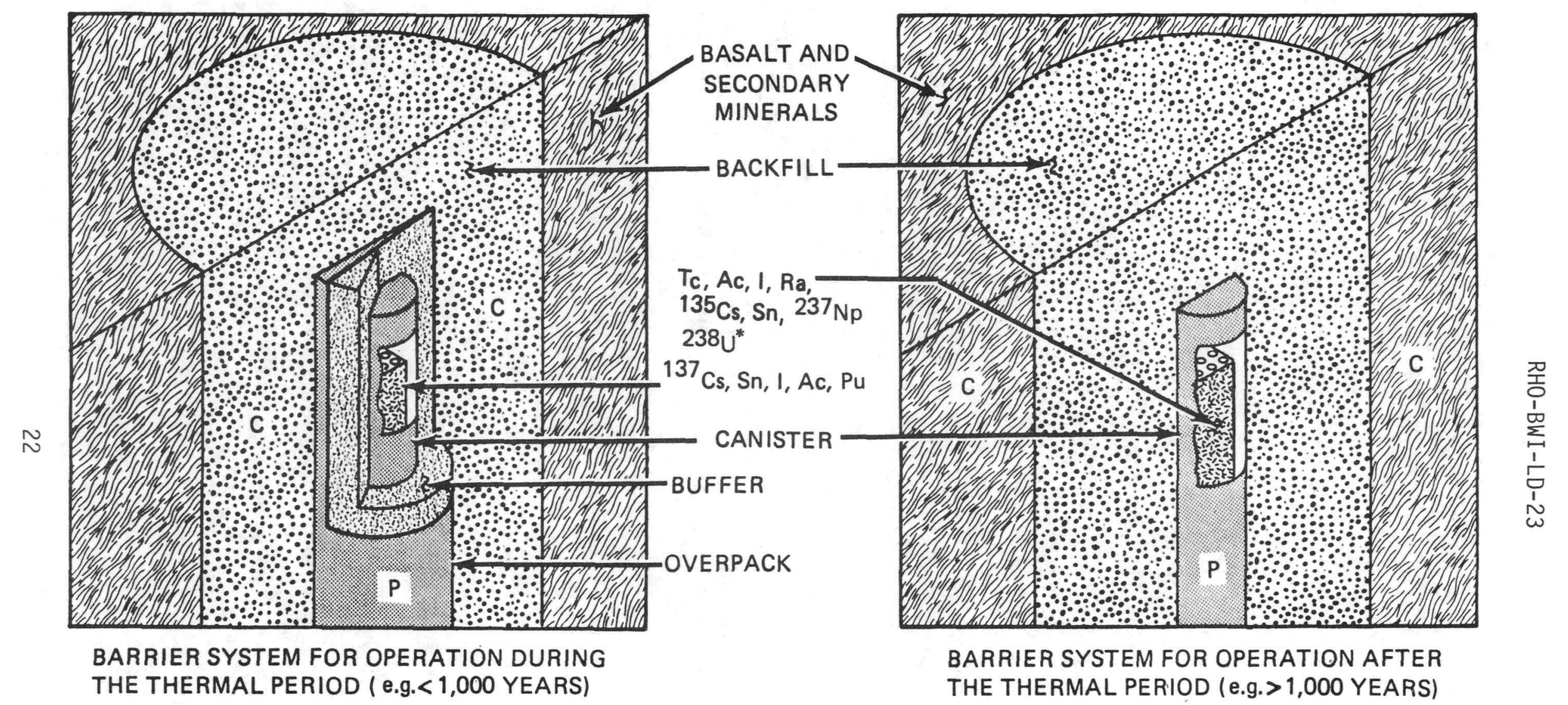

$P=P R I M A R Y$ PHYSICAL BARRIER

$C=$ PRIMARY CHEMICAL BARRIER

bCEB12/79-1

* INCLUDES DAUGHTERS OF ${ }^{238} \mathrm{U}$

FIGURE A-1. Required Components of an Engineered Barrier System as a Function of Time. 
As discussed above, the conceptual design was developed from the realization that repository conditions change with time.

During the thermal period, the groundwater $\mathrm{pH}$ in the near-field region of a repository located in basalt may be low, while oxygen fugacity and temperature may be high. These more extreme conditions may cause rapid corrosion in all but highly corrosion-resistant and expensive materials. This realization and the desire to provide redundancy in the engineered barrier system have resulted in the concept of a canister/overpack assemblage rather than a single, unprotected canister. This assemblage employs a highly corrosion-resistant overpack to protect a less corrosion-resistant, less costly canister with the canister designed to function during the period of geologic control when conditions are milder. An additional part of the assemblage is a buffer which will be housed in the space between the canister and overpack. The buffer functions if the overpack fails during the thermal period and is designed to moderate both $\mathrm{pH}$ and $\mathrm{fO}_{2}$. The buffer is intended only to slow canister corrosion in the event of premature overpack failure.

The inherent solubilities or mobilities of certain hazardous materials (e.g., ${ }^{135} \mathrm{Cs},{ }^{137} \mathrm{Cs},{ }^{129} \mathrm{I},{ }^{99} \mathrm{Tc}$ ) in groundwater require that the engineered barrier system emphasize physical containment of the waste. Therefore, during the thermal period, the overpack and buffer are of primary importance to successful system operation. Later, during the period of geologic control, temperature and oxygen fugacity are low and $\mathrm{pH}$ is high. Under these less corrosive conditions, the canister is more heavily relied upon to provide physical containment. This design goal may be achieved using a number of materials (e.g., Al, Ni) which are either more stable than the overpack under the reducing geologic conditions likely in a repository in basalt or are considerably cheaper than the overpack and still relatively corrosion resistant (e.g., iron-based alloys). Providing a separate canister and overpack and separating their functions result in a set of physical barriers which is likely to be both less expensive and more reliable than a single, unprotected canister of highly corrosion-resistant, but expensive material.

Acting in support of the physical barriers are the chemical barriers. During the thermal period, the prevailing high temperature and low $\mathrm{pH}$ will promote waste-form dissolution. Early in repository history, the waste will be extremely toxic because it will contain its greatest abundance of radionuclides, including the energetic (and hazardous) radionuclides ${ }^{137} \mathrm{Cs}$ and ${ }^{9} \mathrm{Sr}$. Therefore, an engineered barrier system must provide a mechanism for rapid, efficient, and early removal of hazardous materials from contaminated groundwater in the event of failure of the physical barriers. The present conceptual system provides a reactive backfill to surround the assemblage of physical containers. As conceived, the backfill will be a composite material, perhaps consisting of two concentric layers; one of finely crushed basalt plus additives surrounded by one of bentonite clay plus additives. The clay barrier, positioned on the outside of the package, will initially prevent access of water to the canister/overpack. Later, as groundwater penetrates the barrier (either by diffusion, capillary action, or migration through fractures), the low permeability of the clay will create a moderately stagnant environment. These near-static conditions will enhance the ability of the basaltplus-additives layer to extract contaminants from groundwater by thermal 
reaction. Finally, radionuclides escaping the backfill must pass through the basalt geology before reaching any aquifer. Thus, during the thermal period, the geology can be relied upon as a secondary chemical barrier to radionuclide migration.

As with the physical barriers, the relative importance of the chemical barriers changes with time. This change results from the drop in temperature as the heat-producing radionuclides decrease in abundance. Under the low temperatures $\left(65^{\circ} \mathrm{C}\right)$ prevailing during the period of geologic control, thermaliy driven reactions stop or become very sluggish. Under these conditions, it is unlikely that the backfill will efficiently extract hazardous material by reaction. Indeed, the operative extractive process at low temperatures is likely to be sorption. Since sorptive extraction usually requires long path lengths, the geology becomes the primary chemical barrier, with secondary support provided by the backfill.

In summary, the conceptual engineered barriers system for spent fuel in a repository located in basalt includes both chemical and physical barriers, with emphasis placed on physical containment. The relative importance of individual components within these two barrier systems changes with time because repository conditions change with time. During the thermal period, the overpack is the most heavily relied upon physical barrier and the backfill is the primary chemical barrier. During the period of geologic control, the canister is the most heavily relied upon physical barrier and the geology is the primary chemical barrier.

Ultimately, the extent of the engineered barrier system depends on wasteform solubility. Therefore, a barrier system must be designed not only for compatibility with the environment, but also to accommodate or prevent potential radionuclide release in the event water reaches the emplaced waste. Utilizing the reasoning developed above, some candidate materials for a barrier system used to dispose of spent fuel in basalt include:

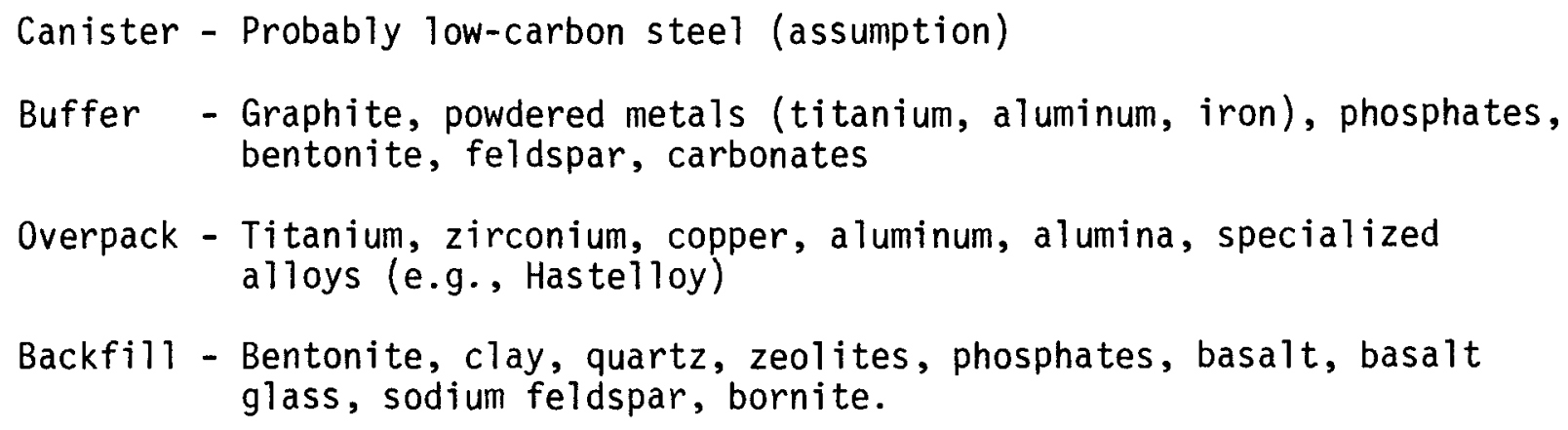
bentonite, feldspar, carbonates

Overpack - Titanium, zirconium, copper, aluminum, alumina, specialized alloys (e.g., Hastelloy)

Backfill - Bentonite, clay, quartz, zeolites, phosphates, basalt, basalt glass, sodium feldspar, bornite.

These candidate materials have been selected on the basis of published data, indicating that they possess the prerequisite qualities demanded by the component function (see section entitled Backfill). These candidates can be screened to eliminate clearly unreasonable choices (such as a precious metal overpack) and then be examined for stability. The best candidate can then be selected on the basis of expected repository performance. In order to make these decisions objectively, it is required that recognized decision-making techniques be employed where possible. 
RHO-BWI-LD-23

\section{DEFINITION OF SYSTEM PERFORMANCE REQUIREMENTS}

The BWIP is considering a technique for engineered barrier system design which will be used to define a permissible composition for contaminated groundwater exiting a repository; thus defining acceptable barrier performance requirements. The technique requires acceptance of dose-to-man limits (e.g., U.S. Environmental Protection Agency standards) as the criteria controlling waste package design. In this approach, acceptable dose-to-man limits are divided by a safety factor and the resulting limits are processed through a model which utilizes thermodynamic data in conjunction with hydrologic flow to approximate radionuclide migration. The resulting calculations specify a permissible source term. This process is essentially the reverse of far-field models which combine leak path, migration, and risk-consequence analysis.

It is envisioned that this technique can be used to generate a comprehensive format for engineered barrier design. Once conceived, the barrier will be tested by experimentation and verified by thermodynamic modeling of the near field as a function of time.

\section{REFERENCES}

ANS, 1979, "American Nuclear Society Policy Statements," Nuclear News, November 1979.

ARHCO, 1974, Retrievable Surface Storage Facility Alternative Concepts Engineering Studies, ARH-2888 REV, Atlantic Richfield Hanford Company, Richland, Washington, and Kaiser Engineers, Oakland, California.

Barnes, M. W. and B. E. Scheetz, 1979, "Laboratory Alteration of a Columbia River Basalt by Hot Groundwater: An Application to Deep Geological Disposal of Nuclear Waste," Geological Society of America Bulletin, 11, p. 384.

Batch, J. M. and C. A. Heath, 1979, "U.S. Program for Disposal of Radioactive Wastes," in proceedings, International Symposium on the Underground Disposal of Radioactive Wastes, IAEA-SM-243/77, International Atomic Energy Agency and OECD Nuclear Energy Agency, Otaniemi (Helsinki), Finland, July 2-6, 1979.

Bischoff, J. L. and F. W. Dickson, 1975, "Seawater Basalt Interactions at $200^{\circ} \mathrm{C}$, 500 Bars. Implication for Origin of Sea-Floor Heavy Metal- Deposits and Regulation of Seawater Chemistry," Earth Planet Scientific Letter 25, p. 385-397.

Braithwaite, J. W. and M. A. Molecke, 1979, Nuclear Waste Canister Corrosion Studies Pertinent to Geologic Isolation, SAND 79-1935 J, Sandia Laboratories, Albuquerque, New Mexico. 
DOE and USGS, 1979, Technical Summary to the Earth Sciences Technical Plan for Mined Geologic Disposal of Radioactive Waste, Draft 2, U.S. Department of Energy and U.S. Geological Survey, Washington, D.C.

EPA, 1979, Environmental Standards for Disposal of Radioactive Waste, Draft 7 , 40 CFR 191, Subpart B, U.S. Environmental Protection Agency, Washington, D.C.

Hardy, M. P. and G. Hocking, 1978, Numerical Modeling of Rock Stresses within a Basalt Nuclear Waste Repository: Phase II - Parametric Design Studies, RHO-BWI-C-23, Rockwell Hanford Operations, Richland, Washington, 303 p.

IRG, 1979, Report to the President by the Interagency Review Group on Nuclear Waste Management, TID-29442, Washington, D.C.

Johnson, A. B., 1977, Behavior of Spent Nuclear Fuel in Water Storage, BNWL-2256, Battelle, Pacific Northwest Laboratory, Richland, Washington.

Moore, E. L. and D. B. Calmus, 1978, Commercial Waste Packaging Program, Radioactive Waste Package Acceptance Criteria, RHO-CD-568, Rockwe11 Hanford Operations, Richland, Washington.

NAE and NAS, 1979, Solidification of High-Level Radioactive Waste, NUREG/CR0895, National Academy of Engineering and National Academy of Sciences, Washington, D.C.

NRC, 1979a, Performance Objectives and Technical Criteria, Draft 7, 10 CFR 60, Subpart E, U.S. Nuclear Regulatory Commission, Washington, D.C.

NRC, 1979b, Policy Relating to the Siting of Fuel Reprocessing Plants and Related Waste Management Facilities, 10 CFR 50, Appendix F, U.S. Nuclear Regulatory Commission, Washington, D.C.

Scheetz, B. E., S. Komarneni, and D. K. Smith, 1979, "Status of Static, Closed System Hydrothermal Alteration Experiments of Simulated Waste Forms," in Basalt Waste Isolation Project Annual Report-Fiscal Year 1979, RHO-BWI-79-100, Rockwell Hanford Operations, Richland, Washington.

Shannon, D. W., 1978, Corrosion of Iron-Base Alloys Versus Alternate Materials in Geothermal Brine, PNL-2456, Pacific Northwest Laboratory, Richland, Washington.

Westerman, R. E., 1979, Preliminary Conceptual Designs for Advanced Packages for the Geologic Disposal of Spent Fuel, PNL-2990, Pacific Northwest Laboratory, Richland, Washington. 


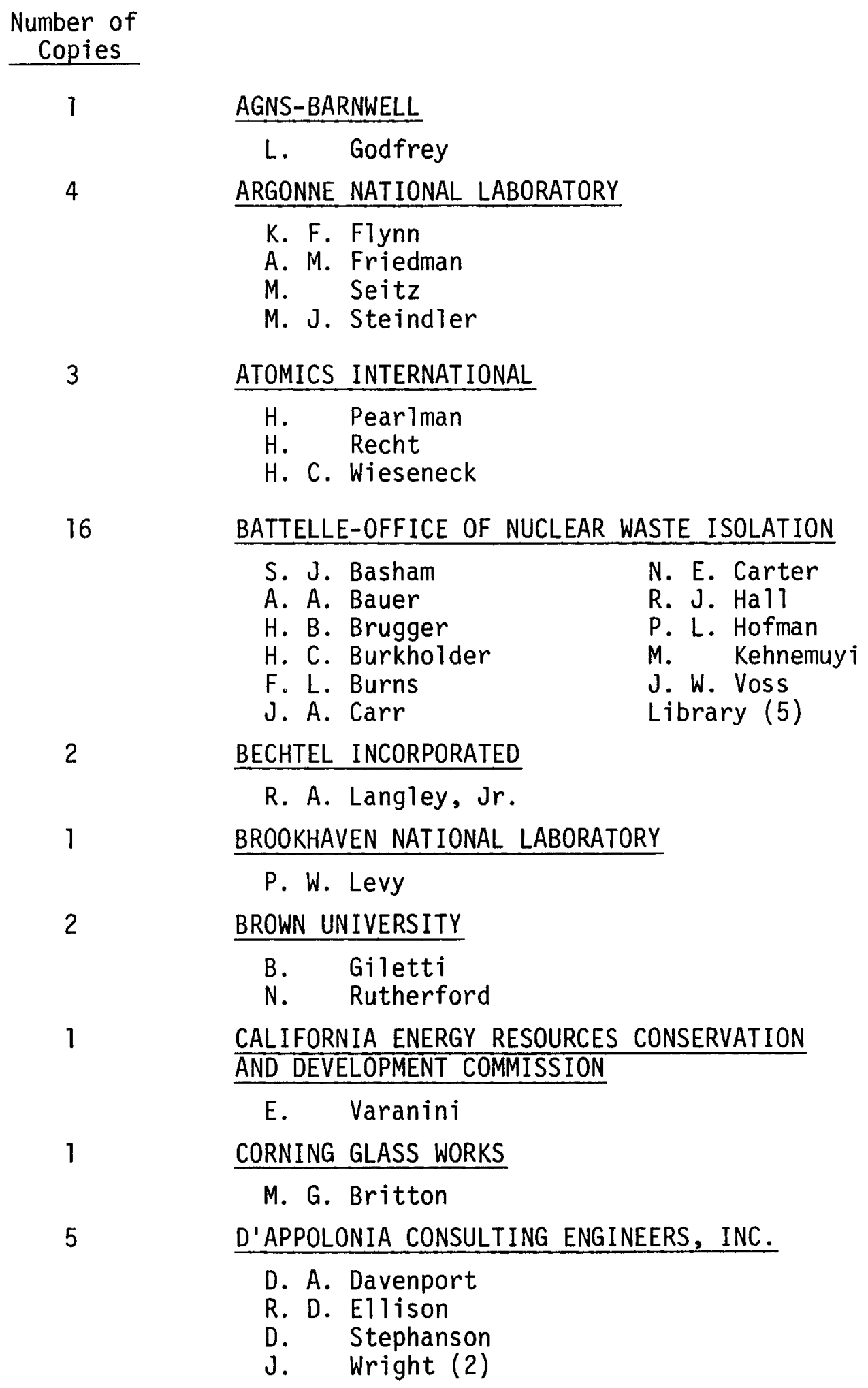




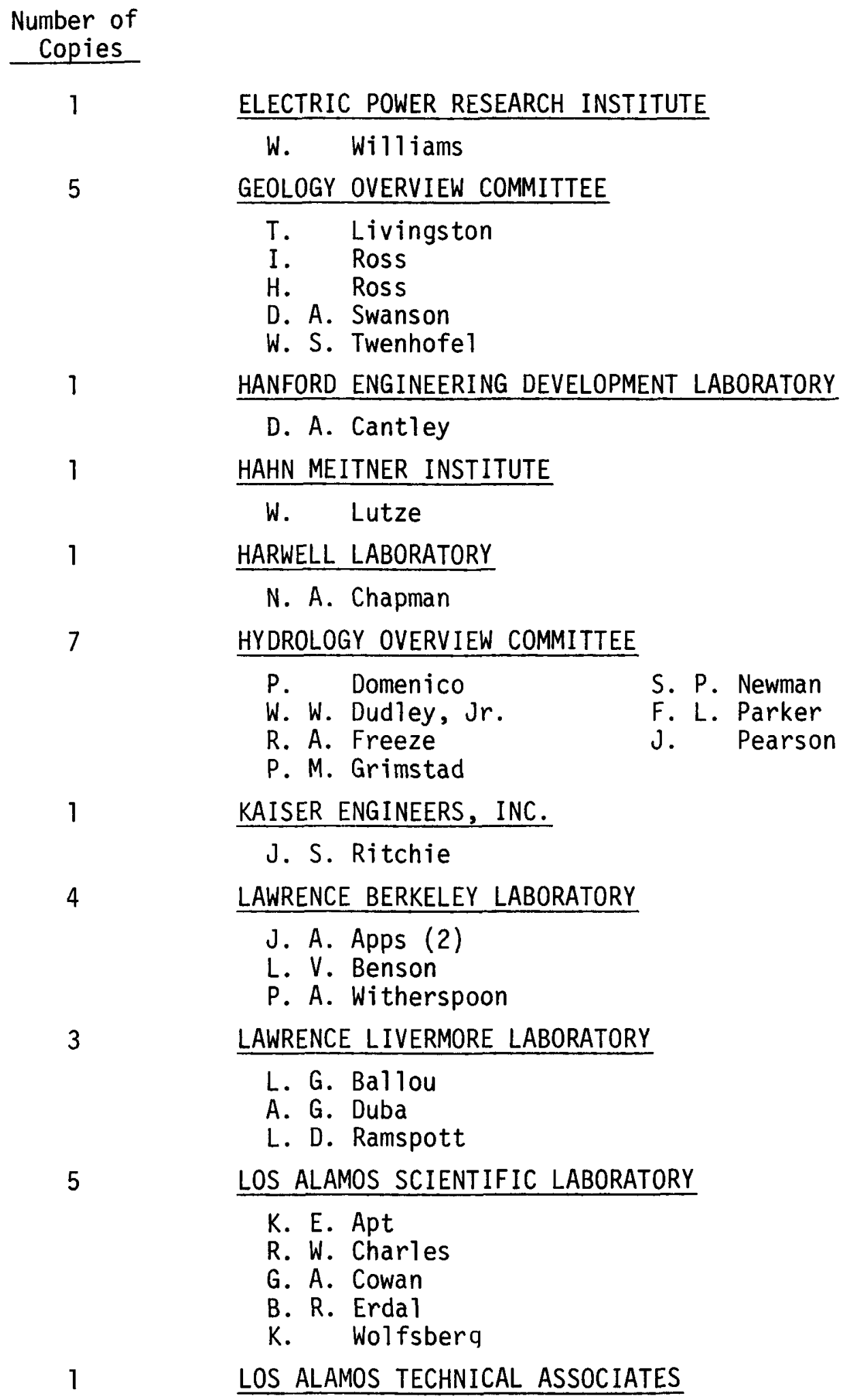

S. E. Logan 
Number of Copies

4

17

2

1

1

7

2

23
NATIONAL ACADEMY OF SCIENCES
W. E. Berg
D. Daley
J. Pomeroy
S. Stuen

NATIONAL ACADEMY OF SCIENCES-

COMMITTEE ON RADIOACTIVE WASTE MANAGEMENT

M. Baram

S. N. Davis

E. L. Draper

P. W. Durbin

J. T. Edsall

M. Eisenbud

J. A. Fay

J. C. Frye

H. L. James

R. E. Kasperson

K. B. Krauskopf

T. R. LaPorte

C. Mawson

F. L. Parker

T. Pigford

R. Roy

E. Wenk, Jr.

NATIONAL BUREAU OF STANDARDS

T. Hahn

T. Yolken

NATIONAL RADIOLOGICAL PROTECTION BOARD

M. D. Hill

NORTH DAKOTA STATE UNIVERSITY

G. J. McCarthy

OAK RIDGE NATIONAL LABORATORY

C. F. Baes, Jr.

D. E. Ferguson

G. W. Beall

H. W. Godbee

J. 0. Blomeke

J. G. Moore

F. W. Dickson

OREGON STATE UNIVERSITY

Department of Chemistry

Department of Geology

PACIFIC NORTHWEST LABORATORY

L. L. Ames

W. F. Bonner

D. J. Bradley

T. D. Chikalla

H. Fullman

O. F. Hill

M. R. Kreiter

J. L. MCElroy

J. E. McGarrah

J. E. Mendel

R. Nelson
A. M. Platt (2)

W. A. Ross

J. M. Rusin

R. J. Serne

D. M. Strachan

R. P. Turcotte

H. H. VanTuyl

R. E. Westerman

J. H. Westsik

E. Wheelwright

Library 
Number of Copies

THE PENNSYLVANIA STATE UNIVERSITY

D. M. Roy

R. Roy

B. E. Scheetz

ROCK MECHANICS OVERVIEW COMMITTEE

N. G. Cook

J. W. Corwine

W. Hustrulid

A. A. Mathews

J. Russell

SANDIA LABORATORIES

E. H. Beckner

R. W. Lynch

C. L. Christensen

M. A. Molecke

F. A. Donath

P. D. O'Brien

R. G. Dosch

E. J. Nowak

J. L. Krumhans ]

A. Lappin

A. E. Stephenson

R. C. Lincoln

W. C. Luth

L. D. Tyler

W. D. Weart

SAVANNAH RIVER LABORATORIES

C. E. Bailey

SCIENCE APPLICATIONS, INC.

D. H. Lester

A. Sugarman

STANFORD RESEARCH INTERNATIONAL

R. Lohman

STATE OF IDAHO GOVERNOR'S OFFICE

C. Jones

STATE OF OREGON GOVERNOR'S OFFICE

K. Woods

STATE OF WASHINGTON GOVERNOR'S OFFICE

J. Wood

SWEDISH NUCLEAR FUEL SUPPLY COMPANY (KBS)

L. B. Nilsson

UNIVERSITY OF ARIZONA

J. J. Daemen 


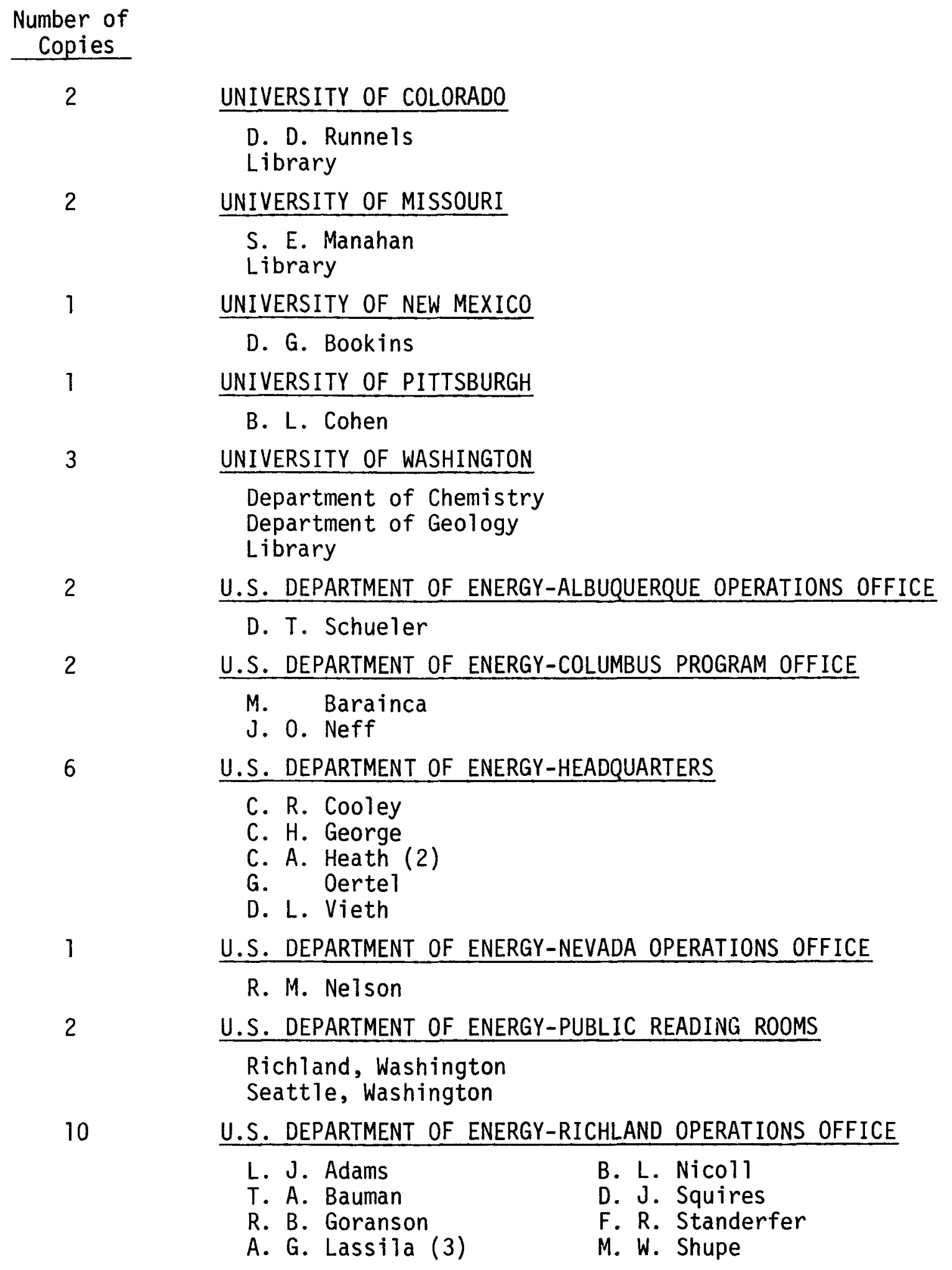




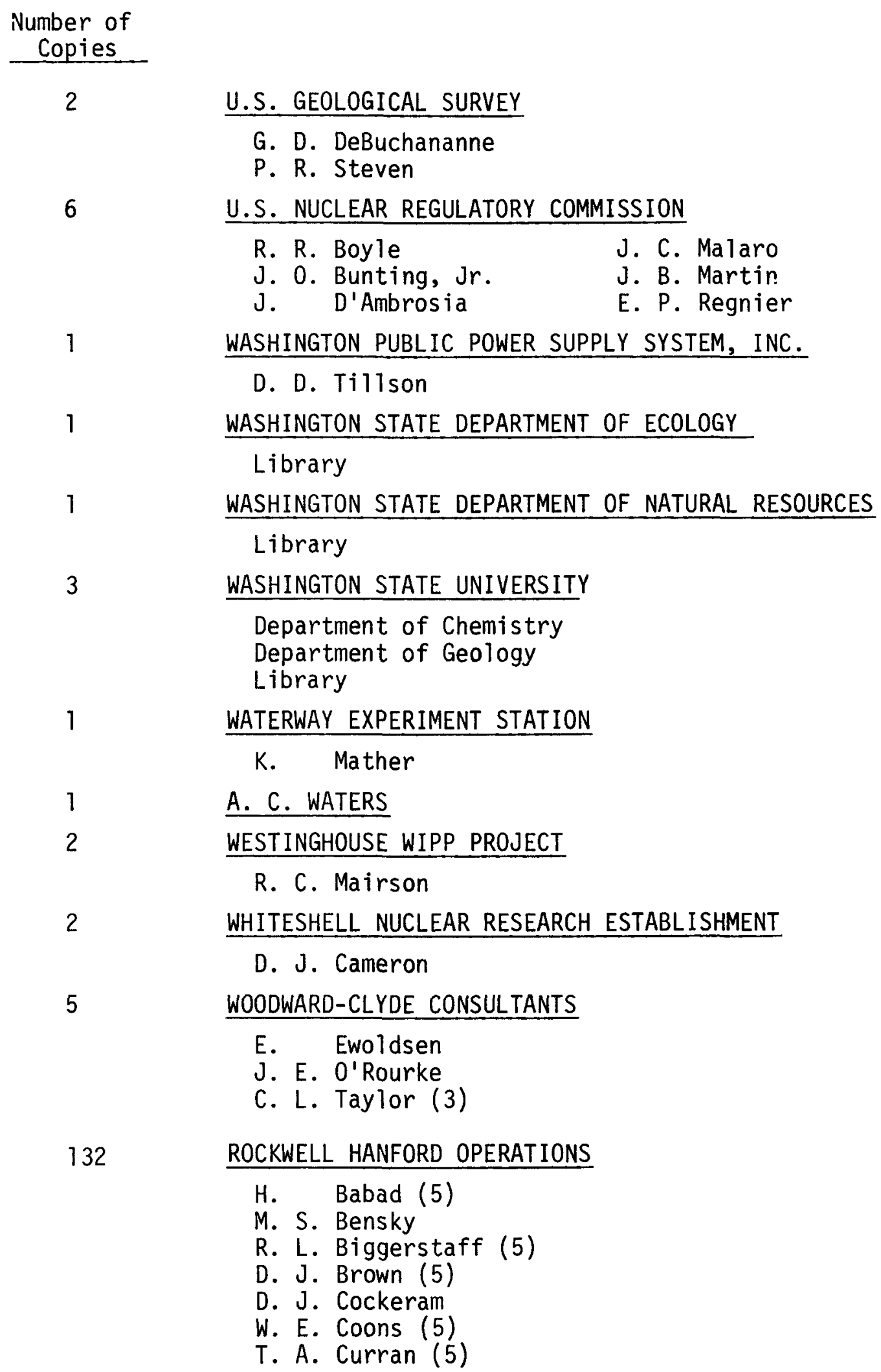


Rockwell Hanford Operations (continued)

R. A. Deju

H. B. Dietz (10)

J. W. Donahue

G. C. Evans

R. J. Gimera

R. N. Gurley (10)

R. D. Hammond

R. E. Isaacson

J. D. Kaser (5)

J. E. Kinzer

E. J. Kosiancic

L. P. McRae

E. L. Moore (5)

C. W. Myers

R. C. Roal

J. H. Roecker

M. J. Smith (5)

C. T. Webster

D. D. Wodrich

Basalt Waste Isolation Project Library (50)

Document Control (4)

Records Retention Center (2) 